\title{
ANALISIS KEBERLANJUTAN USAHATANI HORTIKULTURA SAYURAN PADA LAHAN BERLERENG DI HULU DAS JENEBERANG, SULAWESI SELATAN
}

\author{
Saida \\ Mahasiswa S3 Program Studi PSL-Sekolah Pascasarjana IPB, Bogor 16680 \\ S. Sabiham \\ Widiatmaka \\ Departemen Ilmu Tanah dan Sumberdaya Lahan, Fakultas Pertanian, \\ Institut Pertanian Bogor, Jl. Meranti, Kampus IPB Darmaga, Bogor 16680 \\ S. H. Sutjahjo \\ Departemen Agronomi dan Hortikultura, Fakultas Pertanian
}

\begin{abstract}
This study aimed to analyse the sustainability of vegetables horticultural farming on sloping land in the upstream Jeneberang watershed based on the index evaluation and the status of sustainability by Rap-farm method using Multidimensional Scaling (MDS). Results of ordination technique analysis Rap-farm method of MDS showed that index of vegetables horticultural farming sustainability ranged from 32.19-62.53. Dimension of ecological, economical, institutional, and technological included into sustainable enough category, while social dimension, included into less sustainable category in vegetables horticultural farming systems. Results of leverage Rap-farm analysis showed that from 43 attributes that were analyzed, there were 23 sensitive attributes that affected into the sustainability of vegetables horticultural farming systems in the upstream of Jeneberang watershed.
\end{abstract}

Key words: index and status of sustainability, sensitive attribute, vegetables horticulture farming

Budidaya tanaman hortikultura di lahan berlereng dihadapkan kepada faktor pembatas biofisik seperti lereng yang relatif curam, kepekaan tanah terhadap longsor dan erosi, curah hujan yang relatif tinggi, dan lain-lain. Kesalahan dalam pengelolaan dan pemanfaatan sumberdaya lahan di daerah ini dapat menimbulkan kerusakan atau cekaman biofisik berupa degradasi kesuburan tanah dan ketersediaan air yang dampaknya tidak hanya dirasakan oleh masyarakat di lahan dataran tinggi, tetapi juga di dataran rendah di bawahnya. Empat hal yang mencerminkan penurunan kualitas pertanian lahan kering dataran tinggi yaitu (1) usaha tani yang semakin tidak menguntungkan bagi petani sehingga tidak dapat mencukupi kebutuhan ekonomi keluarganya, (2) menurunnya daya dukung lingkungan yang ditunjukkan oleh meningkatnya kerusakan lingkungan dan rendahnya produktivitas lahan, (3) meningkatnya volume hujan akibat anomali iklim yang memicu terjadinya ledakan serangan hama dan penyakit tanaman sehingga mengakibatkan gagal panen dan kerugian materi yang tidak sedikit, dan (4) hilangnya kemampuan masyarakat untuk membangun modal sosial (social capital) sehingga mereka tidak mampu mengendalikan terjadinya kerusakan lingkungan dan 
sangat tergantung kepada modal usaha yang berasal dari luar (Irianto, et al., 1999, Anyamba, et al., 2006, \& Pranadji, 2006).

Usahatani hortikultura yang diusahakan oleh petani di hulu Daerah Aliran Sungai (DAS) Jeneberang adalah tanaman sayuran dan buah-buahan. Luas lahan yang ditanami tanaman hortikultura sekitar 69.930 ha (18,19\% dari total luas hulu DAS Jeneberang) dalam bentuk tegalan dan kebun (Makaheming, 2003). Usahatani hortikultura diusahakan pada lahan datar hingga berbukit $(0-40 \%)$ sehingga lahan sangat potensial mengalami erosi. Tanaman hortikultura sayuran yang banyak diusahakan adalah kentang, kubis, bawang daun, wortel, cabe dan tomat. Tanaman hortikultura buah-buahan yang banyak diusahakan adalah alpukat, markisa dan rambutan (Said, 2001). Hasil penelitian Tangkaisari (1987) tentang tingkat erosi di DAS Jeneberang bagian hulu menunjukkan bahwa total tanah tererosi pada petak pertanaman bawang daun tanpa konservasi sebesar 80 ton/ha/tahun dan petak pertanaman bawang daun yang berteras saluran sebesar 9 ton/ha/tahun; keduanya melampaui erosi yang dapat diperbolehkan yaitu 8 ton/ha/tahun. Pada tahun 1993 - 1994 erosi yang terjadi di hulu DAS Jeneberang adalah 21,53 ton/ha/tahun, dan tahun 1999 erosi yang terjadi meningkat menjadi 25 ton/ha/tahun (Arsyad, et al., 2000 dalam Makaheming, 2003).

Diduga pola penggunaan lahan di daerah bagian hulu DAS Jeneberang tidak sejalan dengan kemampuan lahannya. Usaha pertanian tanaman hortikultura seperti sayur-sayuran dan buahbuahan dilakukan pada areal dengan kemiringan lereng yang besar tanpa memperhatikan upaya konservasi. Pemanfaatan lahan yang tidak mempertimbangkan atau tidak disesuaikan dengan kemampuan lahannya akan menyebabkan kerusakan tanah dan lingkungan yang lebih parah lagi. Karena besarnya ancaman bahaya erosi dan sedimentasi, tanpa adanya rencana penataan dan pengaturan penggunaan lahan ke arah yang optimal, kemungkinan kerusakan tanah dan lingkungan DAS secara keseluruhan akan menjadi lebih parah di masa yang akan datang dan semakin meluasnya tanah yang tidak produktif. Untuk itu diperlukan penataan dan pengaturan penggunaan lahan yang optimal, sehingga diharapkan kerusakan tanah dan lingkungan dapat ditekan seminimal mungkin dan manfaat ekonomi dapat diperoleh secara maksimal.

Sehubungan dengan hal tersebut, timbul pertanyaan apakah usahatani hortikultura sayuran di hulu DAS Jeneberang dapat berkelanjutan. Usahatani berkelanjutan merupakan implementasi dari pembangunan berkelanjutan. Keraf (2002) mengemukakan bahwa pembangunan berkelanjutan adalah upaya mensinkronkan, mengintegrasikan, dan memberi bobot yang sama terhadap tiga aspek, yaitu aspek ekonomi, sosial budaya dan aspek lingkungan hidup. Debermann (2005) berpendapat bahwa keberlanjutan usahatani diukur dari stabilitas produksi. Dalam mempertahankan keberlanjutan usahatani diperlukan introduksi teknologi. Hasil penelitian Backes (2001) menunjukkan bahwa teknologi introduksi akan diadopsi oleh 53\% petani jika teknologi tersebut sudah dikenal di daerahnya, sedangkan $47 \%$ petani akan mengadopsi jika nilai tambah teknologi tersebut minimal relatif sama dengan teknologi yang ada di petani. OECD (1993), Kay dan Alder (1999) menyebutkan beberapa kriteria yang dapat menjadi acuan pembangunan berkelanjutan, yaitu menyangkut aspek ekologi, ekonomi, sosial budaya serta hukum dan kelembagaan. Menurut Susilo (2003) kriteria atau atribut setiap aspek tersebut merupakan hal penting dalam menilai status keberlanjutan secara cepat (rapid appraisal), dengan menggunakan metode multivariabel non-parametrik yang disebut multi dimentional scaling (MDS).

Penelitian ini bertujuan untuk menentukan indeks dan status keberlanjutan usahatani hortikultura sayuran pada lahan berlereng di hulu DAS Jeneberang. Penelitian ini dilaksanakan di 
hulu DAS Jeneberang, Kabupaten Gowa, Sulawesi Selatan pada bulan April sampai Desember 2009.

\section{METODE PENELITIAN}

Jenis data yang diperlukan dalam analisis keberlanjutan pertanian hortikultura pada lahan berlereng di hulu DAS Jeneberang adalah data primer berupa atribut-atribut yang terkait dengan lima dimensi keberlanjutan usahatani hortikultura sayuran yaitu dimensi ekologi, ekonomi, sosial, kelembagaan, dan teknologi. Data primer bersumber dari responden dan pakar yang dipilih, serta hasil pengamatan di lokasi penelitian. Metode pengumpulan data dilakukan melalui wawancara, diskusi, kuisioner, dan survel lapangan.

Untuk menilai keberlanjutan usahatani hortikultura sayuran berbasis agroekologi secara cepat (rapid appraisal) digunakan metode multi atribut non-parametrik (multi dimentional scaling = MDS), yang merupakan modifikasi dari RAP-farm (The Rapid Appraisal of the Status of Farming). Analisis data dilakukan melalui beberapa tahapan, yaitu: (1) tahap penentuan atribut atau kriteria pengelolaan pertanian hortikultura berkelanjutan, mencakup lima dimensi (ekologi, ekonomi, sosial, kelembagaan, dan teknologi), (2) tahap penilaian setiap atribut dalam skala ordinal berdasarkan kriteria keberlanjutan setiap dimensi, (3) tahap analisis ordinasi nilai indeks keberlanjutan dengan menggunakan metode MDS. Nilai indeks keberlanjutan dalam analisis ini dikelompokkan ke dalam 4 kategori status keberlanjutan, yaitu: 0-25 (buruk), 26-50 (kurang), 51-75 (cukup) dan 76-100 (baik). Atribut dan skor yang digunakan dalam menilai keberlanjutan usahatani tanaman hortikultura sayuran pada lahan berlereng di hulu DAS Jeneberang, meliputi dimensi ekologi, ekonomi, sosial, kelembagaan, dan teknologi.

\section{HASIL DAN PEMBAHASAN}

Hasil analisis RAP-Farm multidimensi dengan menggunakan teknik ordinasi melalui metode MDS menghasilkan nilai indeks keberlanjutan usahatani tanaman hortikultura sayuran sebesar 54,01. Nilai indeks keberlanjutan termasuk kategori cukup berkelanjutan karena nilainya berada antara 5175. Nilai indeks keberlanjutan ini diperoleh berdasarkan penilaian terhadap 43 atribut yang tercakup pada lima dimensi yaitu dimensi ekologi (8 atribut), dimensi ekonomi (9 atribut), dimensi sosial (9 atribut), dimensi kelembagaan (8 atribut), dan dimensi teknologi (9 atribut).

Hasil analisis RAP-Farm selain nilai indeks keberlanjutan juga diperoleh nilai stress dan nilai $R^{2}$. Hasil analisis menunjukkan nilai stress sebesar 0,14, artinya berada di bawah 0,25 jadi hasil analisis ini cukup baik. Nilai $\mathrm{R}^{2}$ (koefisien determinasi) menunjukkan keterkaitan antara sistem dengan atribut-atribut yang digunakan. Nilai $R^{2}$ yang didapatkan yaitu sebesar 0,946 menunjukkan bahwa sistem dengan menggunakan atribut-atribut saat ini sudah menjelaskan 94,60\% dari sistem yang ada. Nilai ini menunjukkan bahwa atribut yang digunakan sebagai indikator yang diberi skor (diboboti), mampu menerangkan perilaku sistem usahatani tanaman hortikultura sayuran pada lahan di hulu DAS Jeneberang sebesar 94,60\%. Dengan demikian seluruh atribut dari lima dimensi yang digunakan sudah cukup baik dalam menerangkan kondisi sistem usahatani hortikultura sayuran yang ada saat ini.

Untuk mengetahui indeks keberlanjutan dari masing-masing dimensi serta atribut yang sensitif mempengaruhi keberlanjutan usahatani hortikultura sayuran pada lahan berlereng di hulu DAS Jeneberang, telah dilakukan analisis RAP-Farm dan analisis laverage pada setiap dimensi. 


\section{Dimensi Ekologi}

Hasil analisis indeks keberlanjutan usahatani hortikultura sayuran dimensi ekologi menunjukkan indeks sebesar 52,43. Angka ini menggambarkan bahwa dimensi ekologi pada usahatani hortikultura sayuran pada lahan berlereng di hulu DAS Jeneberang termasuk kategori cukup berkelanjutan karena nilai indeksnya berada pada selang 50-75.

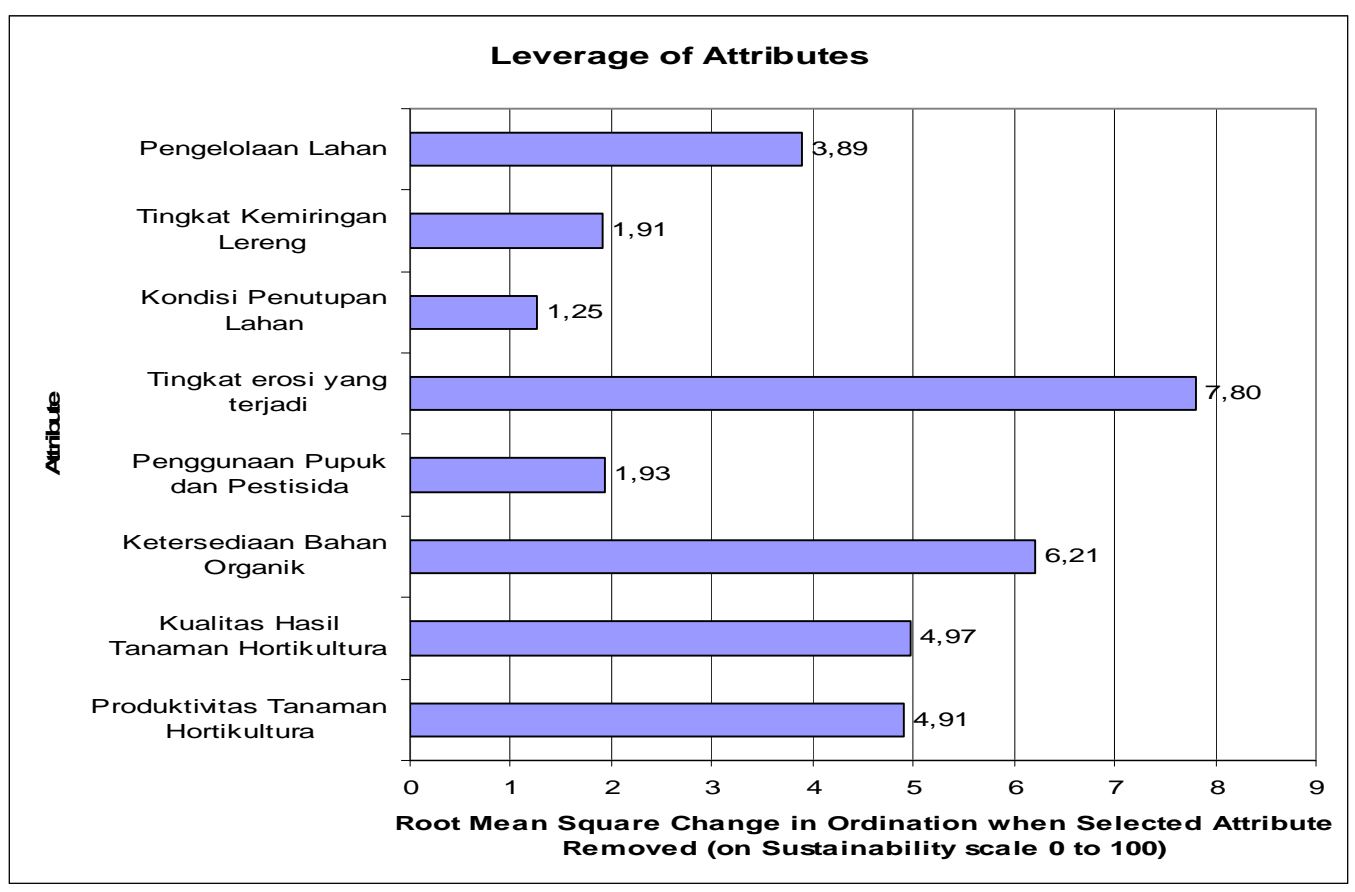

Gambar 1. Atribut sensitif yang mempengaruhi keberlanjutan usahatani sayuran dimensi ekologi.

Dari hasil analisis laverage keberlanjutan dimensi ekologi pada Gambar 1 dapat diketahui bahwa dari delapan atribut yang dianalisis, ada lima atribut yang sensitif mempengaruhi sistem usahatani tanaman hortikultura sayuran, yaitu tingkat erosi yang terjadi, ketersediaan bahan organik, kualitas hasil tanaman hortikultura, produktivitas tanaman hortikultura, dan pengelolaan lahan. Kelima atribut ini sangat erat kaitannya, karena atribut tingkat erosi sangat mempengaruhi produktivitas dan kualitas hasil tanaman hortikultura. Apabila tingkat erosi tinggi maka produktivitas dan kualitas hasil tanaman hortikultura menurun, hal ini disebabkan karena hilangnya lapisan permukaan tanah. Lapisan permukaan ini merupakan lapisan tanah yang subur, mengandung bahan organik dan unsur-unsur hara yang dibutuhkan tanaman sebagai nutrisinya. Apabila nutrisi tanaman tidak terpenuhi sesuai dengan kebutuhannya maka kuantitas dan kualitas hasil tanaman akan menurun. Oleh karena itu yang paling penting untuk dikelola pada dimensi ekologi adalah tingkat erosi yang terjadi, karena akan mempengaruhi atribut-atribut lainnya dalam sistem usahatani hortikultura sayuran. Demikian pula dengan pengelolaan lahan dan ketersediaan bahan organik, kedua atribut ini akan mempengaruhi tingkat erosi. Apabila pengelolaan lahan mengikuti kaidah konservasi tanah dan ketersediaan bahan organik cukup, maka tingkat erosi dapat diminimalkan. 


\section{Dimensi Ekonomi}

Hasil analisis indeks keberlanjutan usahatani hortikultura sayuran dimensi ekonomi menunjukkan indeks sebesar 64,85. Angka ini menggambarkan bahwa dimensi ekonomi pada usahatani hortikultura sayuran pada lahan berlereng di hulu DAS Jeneberang termasuk kategori cukup berkelanjutan karena nilai indeksnya berada pada selang 50-75.

Hasil analisis laverage keberlanjutan ekonomi terlihat pada Gambar 2 yang memperlihatkan bahwa dari sembilan atribut yang dianalisis, terdapat enam atribut yang sensitif mempengaruhi sistem usahatani tanaman hortikultura sayuran, yaitu komoditas unggulan tanaman hortikultura, harga produk komoditas hortikultura, kontribusi terhadap pendapatan petani, pengelolaan hasil pertanian hortikultura, luas lahan garapan, dan ketersediaan pemasaran. Atribut komoditas unggulan tanaman hortikultura sangat besar pengaruhnya terhadap sistem usahatani hortikultura khususnya pada dimensi ekonomi, karena atribut ini mencakup luas areal penanaman dan produksi tanaman hortikultura. Jenis tanaman hortikultura yang banyak diusahakan petani adalah jenis tanaman yang produksinya tinggi dan nilai jual di pasar juga tinggi. Sehingga atribut komoditas unggulan hortikultura sangat terkait dengan pendapatan petani. Apabila komoditas unggulan dengan produktivitas tinggi dan harga yang tinggi serta ketersediaan pemasaran, baik maka akan meningkatkan pendapatan petani. Ddengan produksi yang tinggi dan harga jual yang tinggi maka pendapatan petani akan meningkat. Sebaliknya apabila menanam tanaman nonunggulan dengan produktivitas yang rendah maka kontribusi dari penjualannya ke pendapatan petani menjadi kecil. Demikian pula dengan pengelolaan hasil pertanian hortikultura akan berpengaruh pada kualitas hasil. Apabila pengelolaanya baik maka kualitas hasil dari hortikultura sayuran akan baik pula sehingga nilai jualnya akan meningkat.

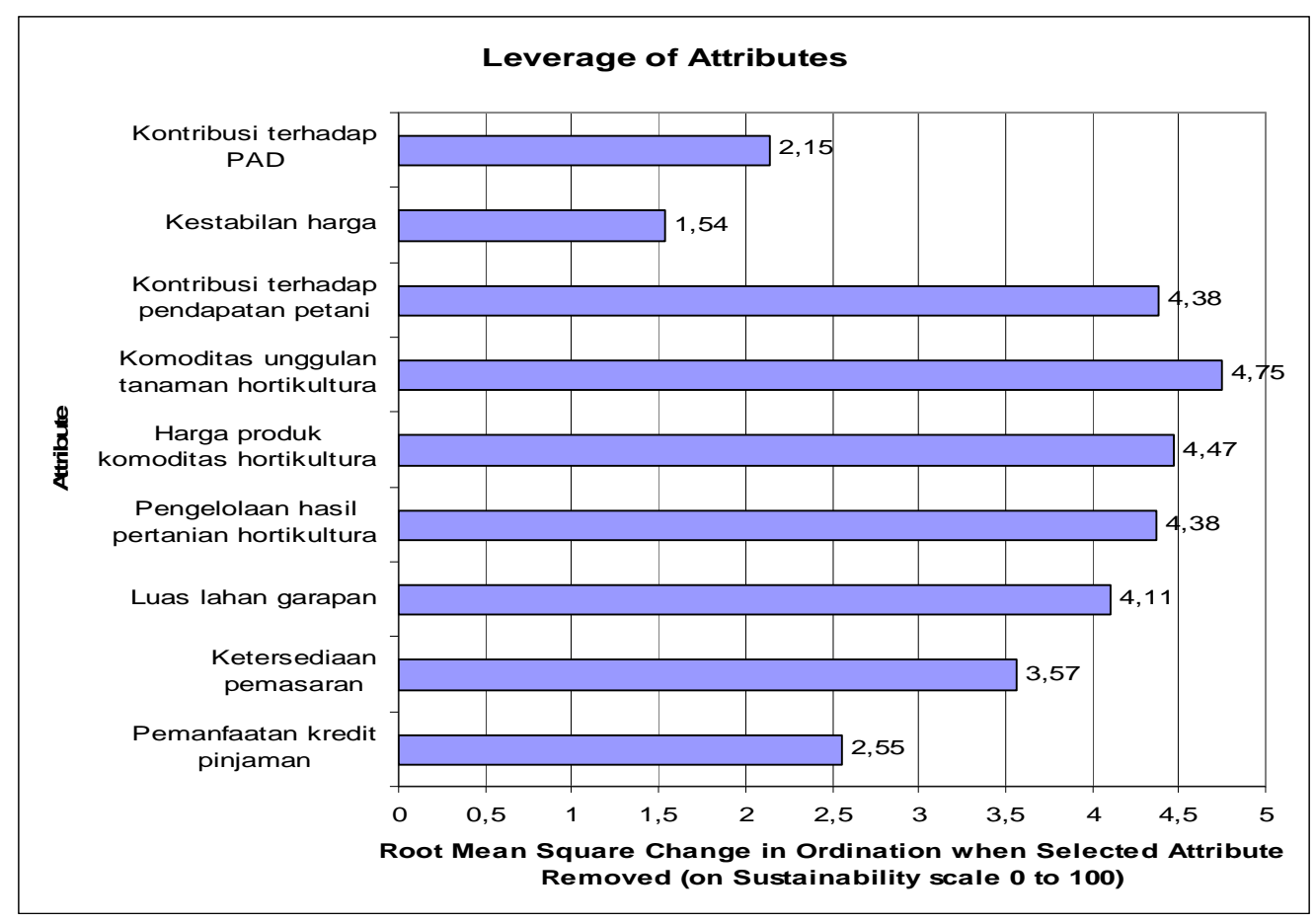

Gambar 2. Atribut sensitif yang mempengaruhi keberlanjutan dimensi ekonomi. 


\section{Dimensi Sosial}

Hasil analisis indeks keberlanjutan usahatani hortikultura sayuran dimensi sosial menunjukkan indeks sebesar 39,58. Angka ini menggambarkan bahwa dimensi sosial pada usahatani hortikultura pada lahan berlereng di hulu DAS Jeneberang termasuk kategori kurang berkelanjutan karena nilai indeksnya berada pada selang 25-50.

Hasil analisis laverage keberlanjutan dimensi sosial pada Gambar 3 memperlihatkan bahwa dari sembilan atribut yang dianalisis, terdapat lima atribut yang sensitif mempengaruhi sistem usahatani tanaman hortikultura sayuran, yaitu intensitas penyuluhan dan pelatihan mengenai teknologi ramah lingkungan, adopsi teknologi konservasi tanah, eksistensi layanan pemerintah, pengetahuan masyarakat tentang lingkungan, persepsi masyarakat tentang partisipatori, dan persepsi masyarakat terhadap upaya konservasi tanah. Atribut intensitas penyuluhan dan pelatihan teknologi ramah lingkungan sangat besar pengaruhnya terhadap sistem usahatani hortikultura sayuran khususnya pada dimensi sosial, karena atribut ini dapat mengubah perilaku petani dalam berusahatani hortikultura sayuran. Apabila atribut intensitas penyuluhan dan pelatihan teknologi ramah lingkungan dilakukan dengan baik, maka akan mengubah sistem usahatani hortikultura, karena subjek atau pelaku dari sistem mengalami perubahan.

\section{Dimensi Kelembagaan}

Hasil analisis indeks keberlanjutan usahatani hortikultura sayuran dimensi kelembagaan menunjukkan indeks sebesar 56,45. Angka ini menggambarkan bahwa dimensi kelembagaan pada usahatani hortikultura sayuran pada lahan berlereng di hulu DAS Jeneberang termasuk kategori cukup berkelanjutan karena nilai indeksnya berada pada selang 50-75.

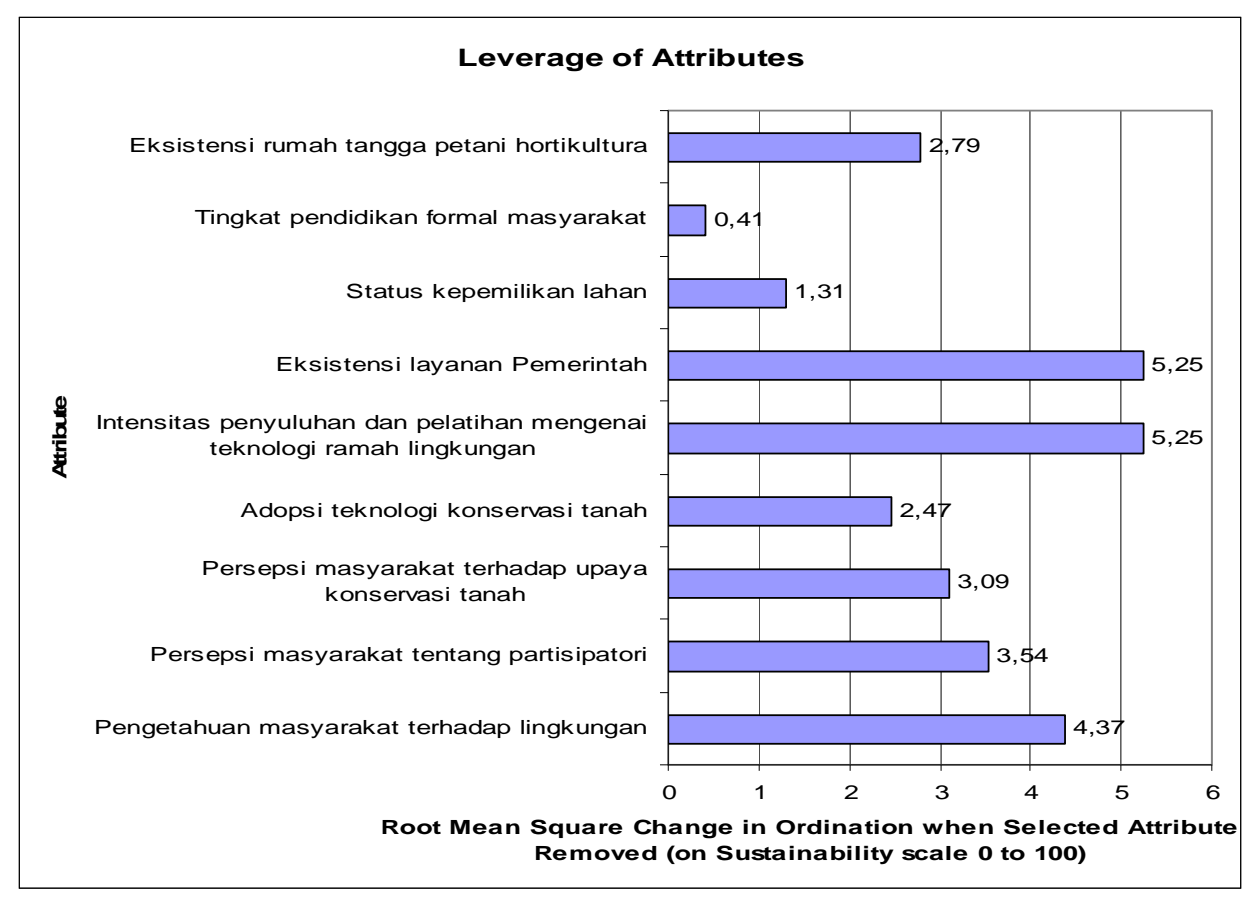

Gambar 3. Atribut sensitif yang mempengaruhi keberlanjutan dimensi sosial pada usahatani hortikultura sayuran. 
Hasil analisis laverage keberlanjutan dimensi kelembagaan pada Gambar 4 memaparkan bahwa dari delapan atribut yang dianalisis, terdapat dua atribut yang sensitif mempengaruhi sistem usahatani tanaman hortikultura sayuran, yaitu keberadaan kelompok tani dan intensitas pertemuan kelompok tani. Atribut keberadaan kelompok tani sangat besar pengaruhnya terhadap sistem usahatani hortikultura khususnya pada dimensi kelembagaan, karena atribut ini merupakan wadah bagi petani hortikultura sayuran untuk menyampaikan aspirasinya dan melalui wadah ini dapat pula berfungsi sebagai fasilitas untuk menjalin kerjasama dengan pihak atau lembaga lainnya. Apabila atribut keberadaan lembaga kelompok tani sebagai dasar diperkuat dan dilakukan dengan baik maka akan mengubah sistem usahatani hortikultura sayuran, karena inti untuk berkembang ada pada kelompok tani. Atribut kelompok tani mempunyai keterkaitan yang sangat erat dengan atribut lainnya yang ada dalam dimensi kelembagaan. Demikian halnya dengan intensitas pertemuan kelompok tani, apabila intensitasnya meningkat dan dilaksanakan secara rutin, maka kelompok tani akan semakin maju dan berkembang. Hal ini disebabkan dalam pertemuan kelompok tani akan terjadi tukar pengalaman dan ide-ide cemerlang yang dapat diterapkan dalam melakukan usahatani hortikultura sayuran.

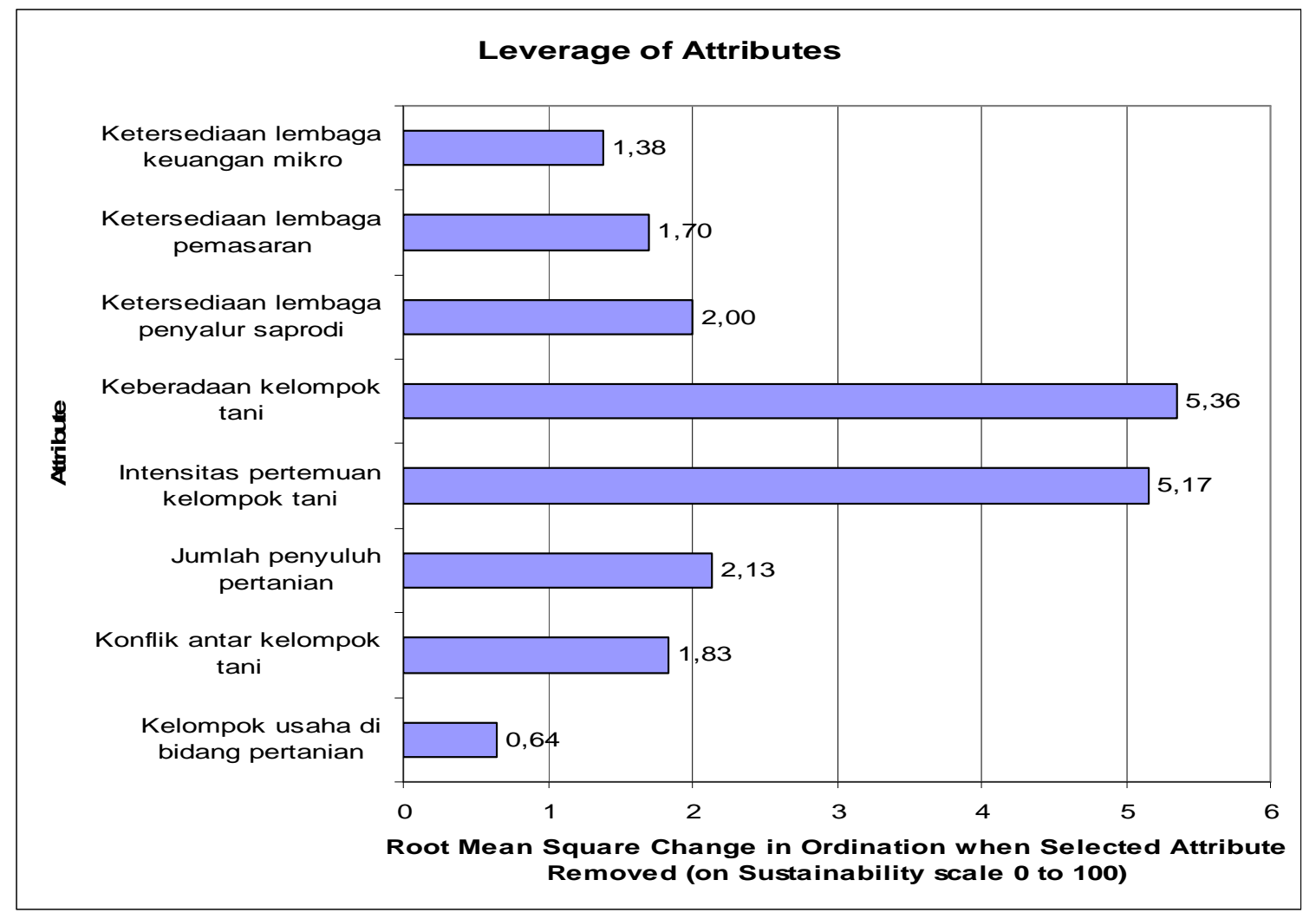

Gambar 4. Atribut sensitif yang mempengaruhi keberlanjutan dimensi kelembagaan. 


\section{Dimensi Teknologi}

Hasil analisis indeks keberlanjutan usahatani hortikultura dimensi teknologi menunjukkan indeks keberlanjutan sebesar 56,71. Angka ini menggambarkan bahwa dimensi teknologi pada usahatani hortikultura pada lahan berlereng di hulu DAS Jeneberang termasuk kategori cukup berkelanjutan karena nilai indeksnya berada pada selang 50-75.



Gambar 5. Atribut sensitif yang mempengaruhi keberlanjutan dimensi teknologi.

Hasil analisis laverage keberlanjutan dimensi teknologi seperti terlihat pada Gambar 5 yang menggambarkan bahwa dari sembilan atribut yang dianalisis, terdapat lima atribut yang sensitif mempengaruhi sistem usahatani tanaman hortikultura sayuran, yaitu teknik penggunaan mulsa, penggunaan pupuk organik dan biofertilizer, teknologi pembuatan pupuk organik, intensitas penggunaan pestisida, dan teknologi pembuatan biopestisida. Kelima atribut ini sangat besar pengaruhnya terhadap sistem usahatani hortikultura sayuran khususnya pada dimensi teknologi, karena atribut ini menentukan kuantitas dan kualitas produksi hortikultura sayuran. Apabila keempat atribut ini dilaksanakan dengan baik maka akan mengubah sistem usahatani hortikultura. Dan keempat atribut ini mempunyai keterkaitan yang sangat erat dengan atribut lainnya yang ada dalam dimensi teknologi khususnya dan atribut lain pada dimensi yang lainnya.

Diagram layang nilai indeks keberlanjutan dari lima dimensi untuk lima komoditas unggulan hortikultura sayuran di hulu DAS Jeneberang tersaji pada Gambar 6. Dari diagram layang-layang ini dapat diketahui bahwa masing-masing dimensi dari setiap komoditas mempunyai nilai indeks keberlanjutan yang berbeda-beda sehingga memerlukan pengelolaan yang berbeda pula. Dimensi 
yang harus diutamakan untuk menjadi prioritas dalam pengelolaannya adalah dimensi dengan status kurang berkelanjutan, sehingga dapat meningkat statusnya menjadi baik atau cukup berkelanjutan.

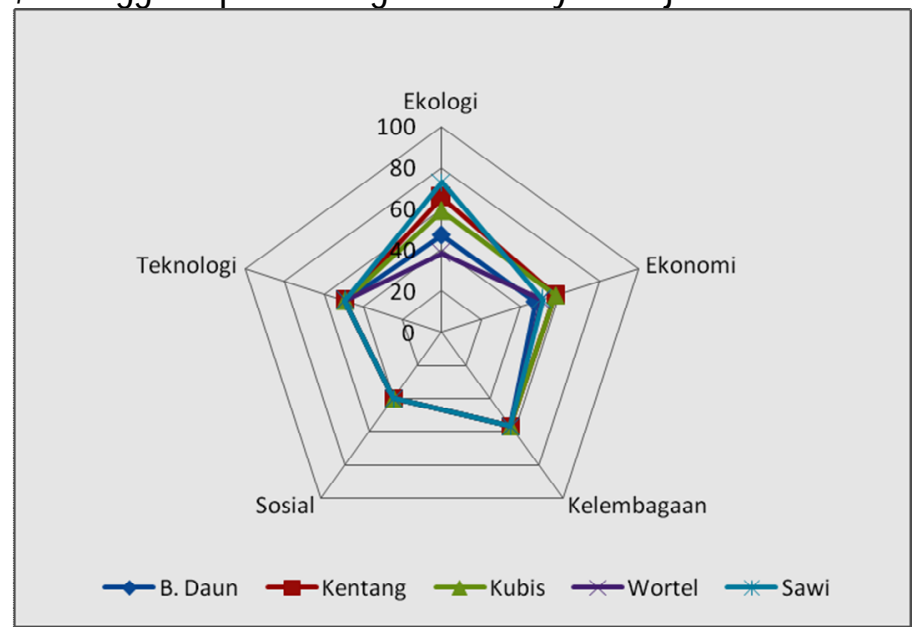

Gambar 6. Diagram layang-layang analisis indeks dan status keberlanjutan sistem usahatani hortikultura sayuran pada lahan berlereng di hulu DAS Jeneberang.

Diagram layang-layang pada Gambar 6 memperlihatkan bahwa dimensi sosial untuk semua komoditas mempunyai nilai indeks antara 39,58-39,64 berada pada status kurang berkelanjutan, demikian pula dengan dimensi teknologi untuk semua komoditas sayuran mempunyai indeks antara 49,33-49,34 berada pada status kurang berkelanjutan. Sedangkan dimensi ekologi pada komoditas kentang dengan nilai indeks 65,37 , pada komoditas kubis $(58,99)$, sawi $(72,85)$ statusnya cukup berkelanjutan, dan komoditas bawang daun $(43,12)$ dan komoditas wortel $(38,42)$ statusnya kurang berkelanjutan. Dimensi ekonomi untuk komoditas kentang $(57,96)$, kubis $(57,96)$, wortel $(50,70)$, dan sawi $(51,40)$ berada pada status cukup berkelanjutan, sedangkan komoditas bawang daun $(47,71)$ berada pada status kurang berkelanjutan. Dimensi kelembagaan pada semua komoditas sayuran berada pada status cukup berkelanjutan.

Dimensi sosial dan dimensi teknologi perlu diprioritaskan pengelolaannya sehingga statusnya dapat ditingkatkan menjadi cukup berkelanjutan. Untuk meningkatkan nilai indeks dimensi sosial maka pengelolaannya pada atribut-atribut sensitif yang berpengaruh terhadap keberlanjutan dimensi sosial, terutama mengelola atribut eksistensi layanan Pemerintah, intensitas penyuluhan dan pelatihan mengenai teknologi ramah lingkungan, pengetahuan masyarakat tentang lingkungan, persepsi masyarakat tentang partisipatori, dan persepsi masyarakat terhadap upaya konservasi tanah. Kondisi eksisting usahatani hortikultura sayuran di hulu DAS Jeneberang, layanan Pemerintah terhadap masyarakat tani khususnya petani sayuran belum memenuhi harapan petani. Penyuluhan dan pelatihan mengenai teknologi ramah lingkungan belum intensif dilakukan oleh pihak penyuluh pertanian Kecamatan Tinggimoncong, sehingga hal ini perlu ditingkatkan karena atribut ini yang sangat berperan (atribut sensitif) dalam mempengaruhi sistem usahatani hortikultura sayuran di hulu DAS Jeneberang. Penyuluhan dan pelatihan yang diberikan kepada masyarakat kurang, sehingga pengetahuan masyarakat tentang lingkungan juga rendah. Akibatnya masyarakat dalam berusahatani tidak menerapkan kaidah-kaidah usahatani konservasi, demikian pula dengan persepsi masyarakat tentang partisipatori dan upaya konservasi tanah. Masyarakat belum memahami tentang 
partisipatori, sehingga petani selalu menunggu bantuan dari Pemerintah, keterlibatan masyarakat tani baru pada tahap pelaksanaan.

Lima komoditas unggulan sayuran yang dianalisis indeks keberlanjutannya menunjukkan bahwa komoditas bawang daun yang memiliki indeks keberlanjutan empat dari lima dimensi (ekologi, ekonomi, sosial, dan teknologi) statusnya kurang berkelanjutan, dimensi kelembagaan statusnya cukup berkelanjutan. Komoditas wortel memiliki indeks keberlanjutan untuk dimensi ekonomi dan kelembagaan statusnya cukup berkelanjutan, sedangkan tiga dimensi lainnya statusnya kurang berkelanjutan. Komoditas kentang, kubis, dan sawi memiliki indeks keberlanjutan dimensi ekologi, ekonomi, dan kelembagaan statusnya cukup berkelanjutan, sedangkan dua dimensi lainnya masuk kategori kurang berkelanjutan.

Hasil analisis MDS pada Tabel 1, menunjukkan nilai stress untuk semua dimensi dan multidimensi memiliki nilai lebih kecil dari 0,25 yaitu berkisar antara 0,13-0,16. Semakin kecil nilai stress semakin baik data yang digunakan. Artinya pengaruh galat terhadap penilaian suatu atribut adalah sangat kecil, sehingga dapat diabaikan. Sedangkan nilai koefisien determinasi $\left(R^{2}\right)$ di setiap dimensi dan multidimensi berkisar antara 0,93-0,95, nilai-nilai ini cukup tinggi dan mendekati angka 1. Hal ini menunjukkan bahwa ada korelasi yang erat antara atribut-atribut dalam suatu dimensi yang diuji coba. Kedua parameter statistik ini (nilai stress dan $\mathrm{R}^{2}$ ) menunjukkan bahwa seluruh atribut yang digunakan di setiap dimensi pada usahatani hortikultura sayuran sudah cukup baik untuk menerangkan keberlanjutan sistem usahatani hortikultura sayuran di hulu DAS Jeneberang.

Tabel 1. Parameter Statistik (Goodness of fit) dari Analisis Indeks dan Status Keberlanjutan Usahatani Hortikultura Sayuran di hulu DAS Jeneberang.

\begin{tabular}{lccccccccccc}
\hline \multirow{2}{*}{ Dimensi } & \multicolumn{10}{c}{ Kenis Hortikultura Sayuran } \\
\cline { 2 - 13 } & \multicolumn{2}{c}{ Kentang } & \multicolumn{1}{c}{ Kawang Daun } & \multicolumn{2}{c}{ Wortel } & \multicolumn{2}{c}{ Sawi } \\
\cline { 2 - 12 } & \multicolumn{2}{c}{ Nilai } & $\mathrm{R}^{2}$ & \multicolumn{1}{c}{ Nilai } & $\mathrm{R}^{2}$ & Nilai & $\mathrm{R}^{2}$ & Nilai & $\mathrm{R}^{2}$ & Nilai & $\mathrm{R}^{2}$ \\
& Stress & & Stress & & Stress & & Stress & & Stress & \\
\hline Ekologi & 0,14 & 0,95 & 0,14 & 0,95 & 0,14 & 0,95 & 0,14 & 0,95 & 0,13 & 0,95 \\
Ekonomi & 0,15 & 0,95 & 0,15 & 0,94 & 0,17 & 0,93 & 0,16 & 0,94 & 0,16 & 0,94 \\
Sosial & 0,15 & 0,95 & 0,15 & 0,95 & 0,15 & 0,95 & 0,15 & 0,95 & 0,15 & 0,94 \\
Kelembagaan & 0,15 & 0,94 & 0,15 & 0,94 & 0,15 & 0,94 & 0,15 & 0,94 & 0,15 & 0,94 \\
Teknologi & 0,13 & 0,94 & 0,13 & 0,94 & 0,13 & 0,94 & 0,13 & 0,94 & 0,13 & 0,94 \\
\hline
\end{tabular}

Tabel 2. Hasil Analisis Monte Carlo dan Multidimensi (MDS) untuk Nilai RAP-Farm dengan Selang Kepercayaan 95\%.

\begin{tabular}{|c|c|c|c|c|c|c|c|c|c|c|c|c|c|c|c|}
\hline \multirow[t]{3}{*}{ Dimensi } & \multicolumn{15}{|c|}{ Jenis Hortikultura Sayuran } \\
\hline & \multicolumn{3}{|c|}{ Kentang } & \multicolumn{3}{|c|}{ Kubis } & \multicolumn{3}{|c|}{ Bawang Daun } & \multicolumn{3}{|c|}{ Wortel } & \multicolumn{3}{|c|}{ Sawi } \\
\hline & MDS & $\mathrm{MC}$ & Status & MDS & $\mathrm{MC}$ & Status & MDS & $\mathrm{MC}$ & Status & MDS & $\mathrm{MC}$ & Status & MDS & MC & Status \\
\hline Ekologi & 65,37 & 65,25 & $\mathrm{C}$ & 58,99 & 59,39 & $\mathrm{C}$ & 47,13 & 47,84 & $\mathrm{~K}$ & 38,42 & 40,51 & $\mathrm{~K}$ & 72,85 & 73,90 & $\mathrm{C}$ \\
\hline Ekonomi & 57,96 & 57,92 & C & 57,96 & 57,31 & C & 47,71 & 47,41 & K & 50,70 & 51,61 & C & 51,40 & 52,71 & C \\
\hline Sosial & 39,58 & 40,29 & K & 39,58 & 40,20 & K & 39,58 & 39,64 & K & 39,58 & 39,64 & $\mathrm{~K}$ & 39,58 & 39,84 & $\mathrm{~K}$ \\
\hline Kelembagaan & 56,47 & 55,52 & C & 56,47 & 56,50 & C & 56,47 & 55,91 & C & 56,47 & 56,45 & $\mathrm{C}$ & 56,47 & 56,87 & $\mathrm{C}$ \\
\hline Teknologi & 49,33 & 49,64 & K & 49,34 & 49,64 & K & 49,34 & 49,90 & K & 49,34 & 49,50 & $\mathrm{~K}$ & 49,34 & 49,50 & K \\
\hline
\end{tabular}

Ket: $\mathrm{C}=$ cukup

$\mathrm{K}=$ kurang 
Hasil analisis Monte Carlo dan Multidimesi (Tabel 2) menunjukkan bahwa nilai status indeks keberlanjutan usahatani hortikultura sayuran pada masing-masing dimensi dengan selang kepercayaan 95\%, untuk analisis Multidimensi berkisar antara 32,19-62,52 dan analisis Monte Carlo berkisar antara 38,42-72,85. Dan perbedaan antara keduanya relatif kecil berkisar antara 0,02-2,09. Kecilnya perbedaan nilai indeks keberlanjutan di antara kedua analisis ini mengindikasikan bahwa kesalahan dalam pembuatan skor setiap atribut relatif kecil, ragam pemberian skor akibat perbedaan opini relatif kecil, proses analisis yang dilakukan secara berulang-ulang stabil, dan kesalahan pemasukan data serta data yang hilang dapat dihindari. Perbedaan ini juga menunjukkan bahwa sistem usahatani hortikultura yang dikaji memiliki tingkat kepercayaan yang tinggi. Beberapa parameter hasil uji statistik ini menunjukkan bahwa metode Rap-farm cukup baik untuk dipergunakan sebagai salah satu alat evaluasi keberlanjutan sistem usahatani hortikultura sayuran di hulu DAS Jeneberang secara kuantitatif dan cepat (rapid appraisal).

\section{KESIMPULAN}

Indeks keberlanjutan untuk sistem usahatani hortikultura sayuran berkisar antara 39,58

sampai 64,85. Dimensi ekologi $(52,43)$, dimensi ekonomi $(64,85)$, dimensi kelembagaan $(56,45)$, dan dimensi teknologi $(56,71)$ termasuk status cukup berkelanjutan, sedangkan dimensi sosial $(39,58)$ masuk status kurang berkelanjutan.

Atribut-atribut yang sensitif berpengaruh terhadap keberlanjutan usahatani hortikultura sayuran sebanyak 23 atribut. Atribut sensitif meliputi tingkat erosi yang terjadi, ketersediaan bahan organik, kualitas hasil tanaman hortikultura, produktivitas tanaman hortikultura, pengelolaan lahan, komoditas unggulan tanaman hortikultura, harga produk komoditas hortikultura, kontribusi terhadap pendapatan petani, pengelolaan hasil pertanian hortikultura, luas lahan garapan, ketersediaan pemasaran, intensitas penyuluhan dan pelatihan mengenai teknologi ramah lingkungan, adopsi teknologi konservasi tanah, eksistensi layanan Pemerintah, pengetahuan masyarakat tentang lingkungan, persepsi masyarakat tentang partisipatori, persepsi masyarakat terhadap upaya konservasi tanah, keberadaan kelompok tani, intensitas pertemuan kelompok tani, teknik penggunaan mulsa, penggunaan pupuk organik dan biofertilizer, teknologi pembuatan pupuk organik, intensitas penggunaan pestisida, dan teknologi pembuatan biopestisida. Komoditas wortel yang tingkat keberlanjutannya paling rendah dan komoditas sawi dan kentang yang tingkat keberlanjutannya cukup.

Implikasi kebijakan dari temuan-temuan tersebut adalah peningkatan status keberlanjutan usahatani hortikultura sayuran dapat dicapai melalui kebijakan yang lebih terfokus pada penurunan laju erosi melalui penerapan usahatani konservasi. Penerapan usahatani konservasi perlu ditindaklanjuti dengan penyuluhan yang intensif tentang teknologi konservasi tanah, sehingga akan mengubah persepsi petani dalam melakukan usahatani hortikultura sayuran. Eksistensi layanan Pemerintah juga perlu ditingkatkan, khususnya yang berkaitan dengan usahatani hortikultura sayuran seperti penyediaan bibit unggul, ketersediaan pupuk, dan lembaga pemasaran yang berpihak pada petani.

\section{REFERENSI}

Anonim. (2003). Penyusunan rencana teknik lapangan rehabilitasi lahan dan konservasi tanah Daerah Aliran Sungai (DAS) Jeneberang, Provinsi Sulawesi Selatan. BP-DAS Jeneberang Walanae Provinsi Sulawesi Selatan dan LPPM Universitas Hasanuddin. Makassar. 
Anyamba, A., Chretein, J. P., Small, J., Tucker, C. J., \& Linthicum, K. J. (2006). Developing global climate change anomalies suggest potential disease for 2006-2007. International Journal of Health Geographics, (5), 6-10.

Backes, M.M. (2001). The role of indigenous trees for the conservation of biocultural diversity in traditional agroforestry land use system. Agroforestry Systems J. $52: 119-132$.

Debermann, A. (2005). The development of site specific nutrient management for maize in Asia. Workshop 1-4 May 2005. Brastagi-Indonesia. Puslitbang Tanaman Pangan.

Hardjowigeno, S. \& Widiatmaka. (2007). Evaluasi kesesuaian lahan dan perencanaan tataguna lahan. Yogyakarta: Gadjah Mada University Press.

Irianto, G. S., Duschesne, J., Forest, F., Perez, P., Cudennec, C., Prasetyo, T., \& S. Karama. (1999). Rainfall-runoff harvesting for controlling erosion and sustaining up land agriculture development. Selected paper from The 10th International Soil Conservation Organization Meeting, 24-29 May 1999. p. 431-439.

Kay, D. \& Alder, J. (1999). Coastal planning and management. New York: Routledge.

Keraf, A.S. (2002). Etika lingkungan. Jakarta: Penerbit Buku Kompas. 322p.

Makaheming, Y. (2003). Pola pengelolaan hutan pada hulu DAS Jeneberang Kabupaten Gowa. Tesis yang tidak dipublikasikan, Program Pascasarjana, Universitas Hasanuddin. Makassar.

Nurkin, B. (2005). Upland resource development: Impacts on the Jeneberang Watershed. In: From Sky to sea: Environment and development in Sulawesi. Eds: Wismer, S., Babcock, T., \& B. Nurkin. Department of Geography, University of Waterloo. Canada.

OECD. (1993). Coastal zone management. integreated policies. Organization for economic Cooperation and Development. Paris.

Pranadji, T. (2006). Model pemberdayaan masyarakat pedesaan untuk pengelolaan agroekosistem lahan kering. Disertasi yang tidak dipublikasikan. IPB. Bogor.

Said, A. (2001). Dinamika kondisi sosial ekonomi DAS Jeneberang bagi pengelolaan terpadu waduk Bili-Bili. Profiling Wilayah DAS Jeneberang. Pusat Penelitian Lingkungan Hidup (PPLH)UNHAS. Makassar.

Susilo, B. (2003). Keberlanjutan pembangunan pulau-pulau kecil: Studi kasus kelurahan pulau Panggang dan pulau Pari, kepulauan seribu, DKI Jakarta. Disertasi yang tidak dipublikasikan Program Pascasarjana, Institut Pertanian Bogor. 185p.

Tangkaisari, R. (1987). Penelitian tentang tingkat erosi di sub DAS Jeneberang. Bulletin penelitian universitas Hasanuddin. Ujung Pandang.

Zubair, H. (2005). Sediment control in Bili-Bili reservoir: An application of modeling to determine management option for the Jeneberang River Basin. In: From Sky to Sea: Environment and development in Sulawesi. Eds: Wismer, S., Babcock, T., \& Nurkin, B. Department of Geography, University of Waterloo. Canada. 